\title{
Politics, Architecture and a Wall
}

\author{
ANE GONZALEZ LARA \\ University of New Mexico
}

\begin{abstract}
Following the outcome of a studio that I taught in the US/ Mexico Border and analyzing other proposals, this paper studies the consequences and responses that the wall has created amongst architects and designers and questions the role of architects in the definition of geopolitical boundaries.
\end{abstract}

\section{INTRODUCTION}

One might think that when the President of the United States included in his campaign building a great structure, and creating thousands of jobs in the construction industry, that this would be great news for the architects of the country. But when that structure is a wall dividing two neighbor countries, there are more things coming into play than just getting a wall built.

This situation has caused lots of diverse opinions amongst the architects of the country and has challenged the role of architects in the conflict. It has generated competitions around the issue, publications, conferences and lots of diverse points of view.

This paper will analyze the reactions that the wall has created amongst the architecture community and the role of architects in such conflicts.

\section{THE WALL}

"I would build a great wall, and nobody builds walls better than me, believe me, and I will build them very inexpensively. I will build a great, great wall on our southern border and I will have Mexico pay for that wall." 1

It's been about two years since Donald Trump made this statement when announcing his run for the presidency. During this time, different opinions have been raised about the construction of the wall, some coming from the architectural community.

On February 24th 2017, the Department of Homeland Security, Customs and Border Protection issued a solicitation in electronic format "for the design and build of several prototype wall structures in the vicinity of the United States border with Mexico." 2 This RFP set the fire for this ongoing conversation and became what it seemed like an impossible proposition, into a reality.

For the first call that the Department of Homeland security emitted, more than 600 companies submitted a proposal.
The list included defense contractors, architectural firms, and construction firms. ${ }^{3}$

JuneJuly, a small architectural office based in Los Angeles and New York, was included in this list of companies. Jake Matatyaou and Kyle Hovenkotter, JuneJuly's principals, are educators and teach at $\mathrm{SCl}$-Arch and Pratt respectively. Their appearance in the list of responders to the call caused some sudden controversy in the architectural community.

In JuneJuly's interview with the LA Times reporter Carolina Miranda, Matatyaou asked "If we begin with the fact that we're building a hard border, something physical and material and that it will be built, we start with the question, "What is an aesthetically, humanitarianly minded thing?" while Hovenkotter added "I think the nation-state is a kind of outdated construct. And I think they are creating more political problems than solutions. But I also understand that if there is a system in which to play, you might want to play in it and make the best of it." 4

In a later interview published at the architect's newspaper, JuneJuly stated "In an ideal world, there would be no border and certainly no wall. But given our reality, we feel it is most productive to work within its constraints, so we begin with the reality of the wall as described in the pre-solicitation. Our involvement in the process opens a direct dialogue with those who are making decisions about the future of our southern border." 5

JuneJuly's comments about their desire to make the wall more "aesthetical and humanitarian minded", without challenging the prompt itself, are a good example of the lens from which some architects see their agency in political conflicts.

\section{COMPETITIONS}

Coexisting with the aforementioned controversy, and with the call for proposals launched by the Department of Homeland Security, Third Mind Foundation launched a competition titled "Building the Border Wall?" that also created a lot of adverse opinion against it. (Fig. 1)

The competition was launched by Third Mind Foundation and prompted the participants to "Design a barrier of architectural merit that is realistically priced to build and made of materials that will not only be effective in keeping out waves of illegal immigration, but that will also be relatively 


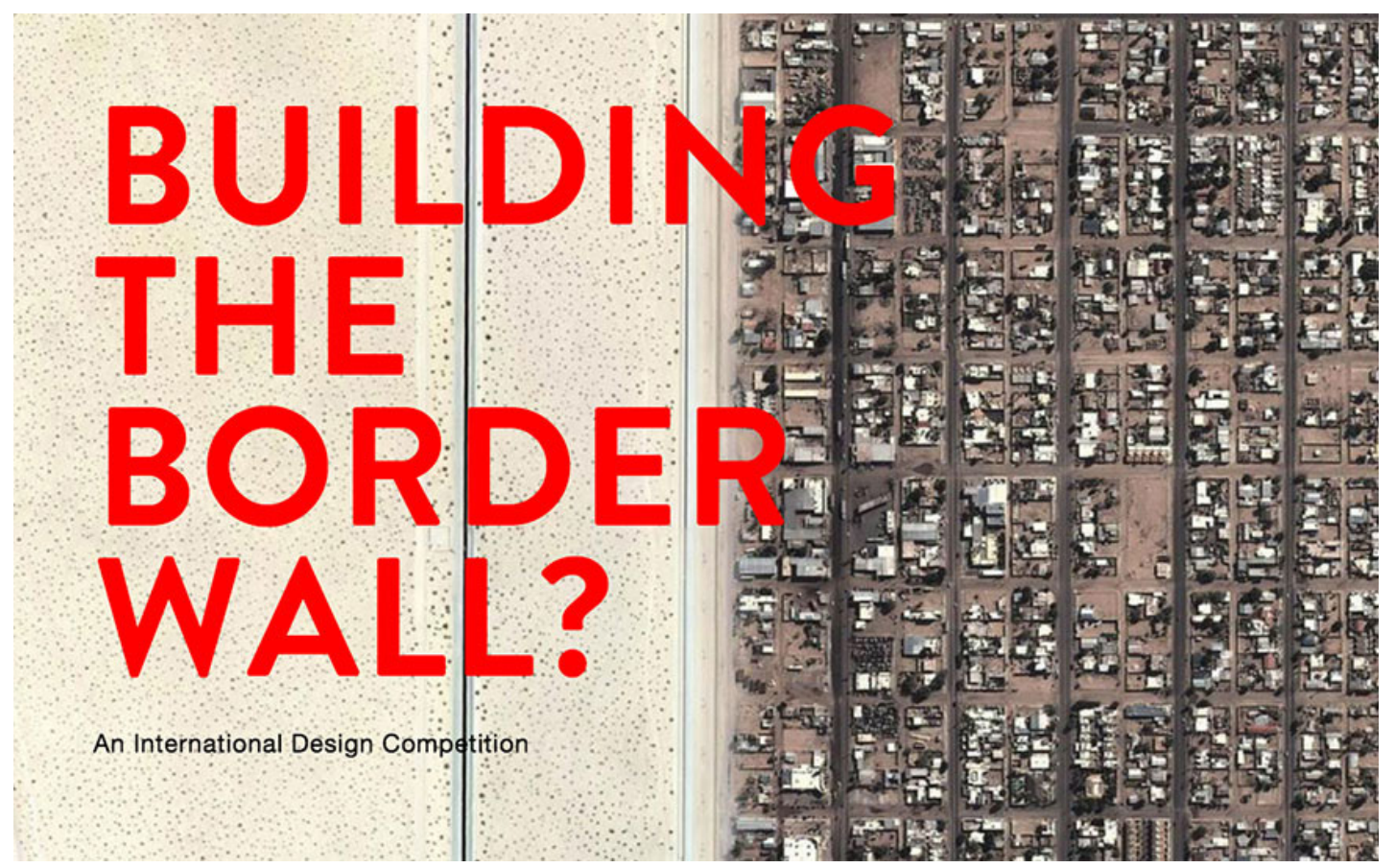

Figure 1: Building The Border Wall, competition launched in 2016 by The Third Mind Foundation.

inexpensive to maintain." ${ }^{16}$ Some architectural websites like Bustler decided not to promote the competition. "We are conflicted about the nature of the competition and fear that it promotes xenophobia. The competition goes against the ethical standards we strive to align ourselves with". ${ }^{7}$ But others, like Archdaily, promoted the competition in their website stirring up the debate about ArchDaily's ethical principles.

Reacting to this opposition, the organizer of the competition added a question mark to the title and made some changes to the brief which was changed and asked the participants "to bring creativity and innovation to bear on the idea of a border barrier." "If not a fence or wall, then what? Can the idea of a wall be combined with architectural activism?" The organizers also added, "We take no position on this issue. We remain politically neutral." 8

As per an article published in the New Republic, one of the chief organizers of the competition admitted that "none of the competition's organizers had visited the border region or seriously researched the issue in preparation for this competition" 9

While some architects are still coexisting in the fine line of the two sides of the debate, other platforms have taken a clear stand on the conflict. The platform "No Ban, No Wall" has supported different rallies against the wall across the country and showed a clear opposition against any kind of wall built on the US/Mexico border.

\section{AIA}

Following the results of the Presidential election, Robert Ivy, Executive Vice President and Chief Executive Officer of the
American Institute of Architects, released a statement on behalf of AIA supporting President Trump's plans to embark on the construction of "new infrastructure".

"The AIA and its 89,000 members are committed to working with President-elect Trump to address the issues our country faces, particularly strengthening the nation's aging infrastructure. During the campaign, President-elect Trump called for committing at least $\$ 500$ billion to infrastructure spending over five years. We stand ready to work with him and with the incoming 115th Congress to ensure that investments in schools, hospitals, and other public infrastructure continue to be a major priority." 10

This statement had mayor repercussion in the architecture community of the country and it even generated the hashtag \#NotMyAIA to join the conversation online.

Following the criticism, Ivy and national president Russ Davidson issued an apologetic video and admitted that "The message that went out was a mistake, and it shouldn't have happened." 11

Surprisingly enough, AIA of New Mexico, Texas, and Arizona, have adopted a formal resolution that opposes the border wall that President Trump envisioned months ago and seems determined to continue funding.

New Mexico's AIA chapter passed a document titled "Resolution on Alternatives on the Border Wall" on September 19, 2017. The document states "The AIA New Mexico Chapter of the American Institute of Architects request that the US Senators and Representatives from New Mexico consider 


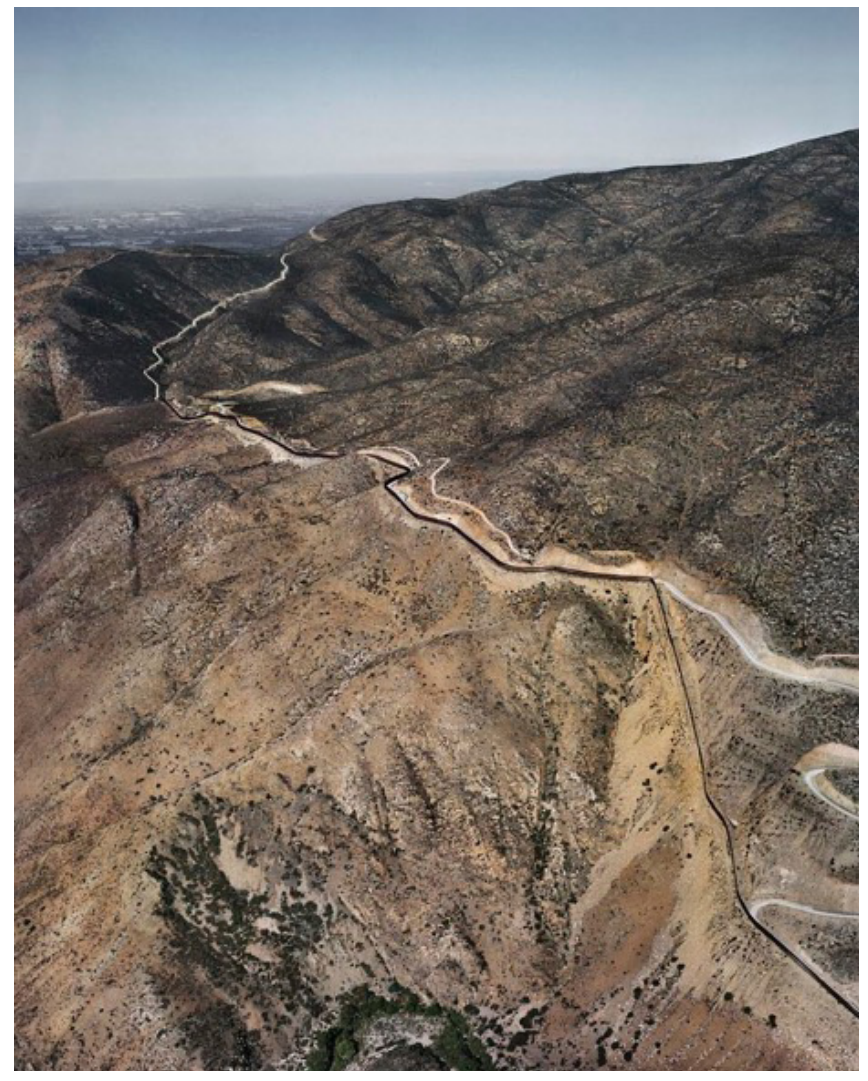

alternatives to the construction of a US/Mexico border wall, and advocate instead for infrastructure projects that will better serve and enrich the public interest while safeguarding our natural environment." 12

\section{CAN ARCHITECTURE BE A-POLITICAL?}

In 2014, the AA of London organized a lecture series named The Architecture Exchange. One of the Lectures was titled "How is Architecture Political?". This lecture was an open discussion to which Chantal Mouffe invited Pier Vittorio Aureli, Reinhold Martin, Ines Weizman and Sarah Whiting as respondents.

In his half an hour lecture, Pier Vittorio Aureli started his presentation with a somewhat ambiguous prompt: "Architecture cannot be political" and "architecture is always political". Pier Vittorio Aureli defended that architecture as a practice has always been "a modus of consensus" and as such, it is not political. He also added that "the profession of architect has been not only a practice dependent on consensus but also an instrument of neutralization and depoliticization of the city". 13

On the other hand, Aureli stated that architecture "is always political even within the most modest job or tiny detail". He also added that "architectural forms always address a spatial condition and any spatial condition always implies an idea of the political... while architectural form is always political, architecture as a discipline and as a profession has always tended to be a-political". One example that he sets for this argument was Guggenheim Helsinki's competition, that was clearly used as a way to create consensus around a very controversial project that is likely to never get built.

In a similar format, in 2013, Storefront for Art and Architecture organized an event related to the launch of the book Architecture and Capitalism: 1845 to the Present, edited by Peggy Deamer 14. Apart from the editor, other three speakers were invited to the venue: Thomas Angotti, Quilian Riano, and Michael Sorkin. The event was presented as a forum where "some of the book contributors and other leading figures in the discourse around politics, economy, architecture and the city presented and discussed some historical and contemporary references on how alternatives have been articulated in the past and how we might be able to articulate them today."

On his remarks, Quilian Riano showed a much more radical opinion than what Aureli or Whiting expressed a year later. Rain stated that "All design is political, there is no such thing as apolitical design".

\section{POLITICAL ARCHITECTURE}

Considering architecture, a field closely related to politics and economics, it has been involved in different political conflicts throughout history.

In 2012, MoMA curated an installation of architectural works that responded to different political conflicts during the last half-century. The exhibition, titled $9+1$ Ways of Being Political: 50 Years of Political Stances in Architecture and Urban Design, also featured the work of Teddy Cruz, Didier Faustino and the collective Raumborberlin titled Occupying Social Borders, 1974, 2011. This installation "sought to be pro-active about conditions of poverty and inequality that requires hands-on solutions and research". (Fig. 3) ${ }^{15}$

Another example of architecture taking political stances is the last Spanish Pavilion in the Venice Biennale. Under the title "Unbuilt", the Spanish Pavilion showcased a series of photographs of incomplete construction projects, along with 55 recent buildings that exemplified "a range of solutions to working under economic constraints". ${ }^{16}$ The pavilion was a critic to the economic recession that Spain went through and that left thousands of buildings unfinished. By 2012, almost the $50 \%$ of the architecture offices in Madrid and Barcelona had to close due to the economic recession that the entire country was undergoing. The pavilion echoed the concerns of thousands of Spanish architects and it was awarded the Golden Lion for the best national pavilion at the 2016 Biennale. 


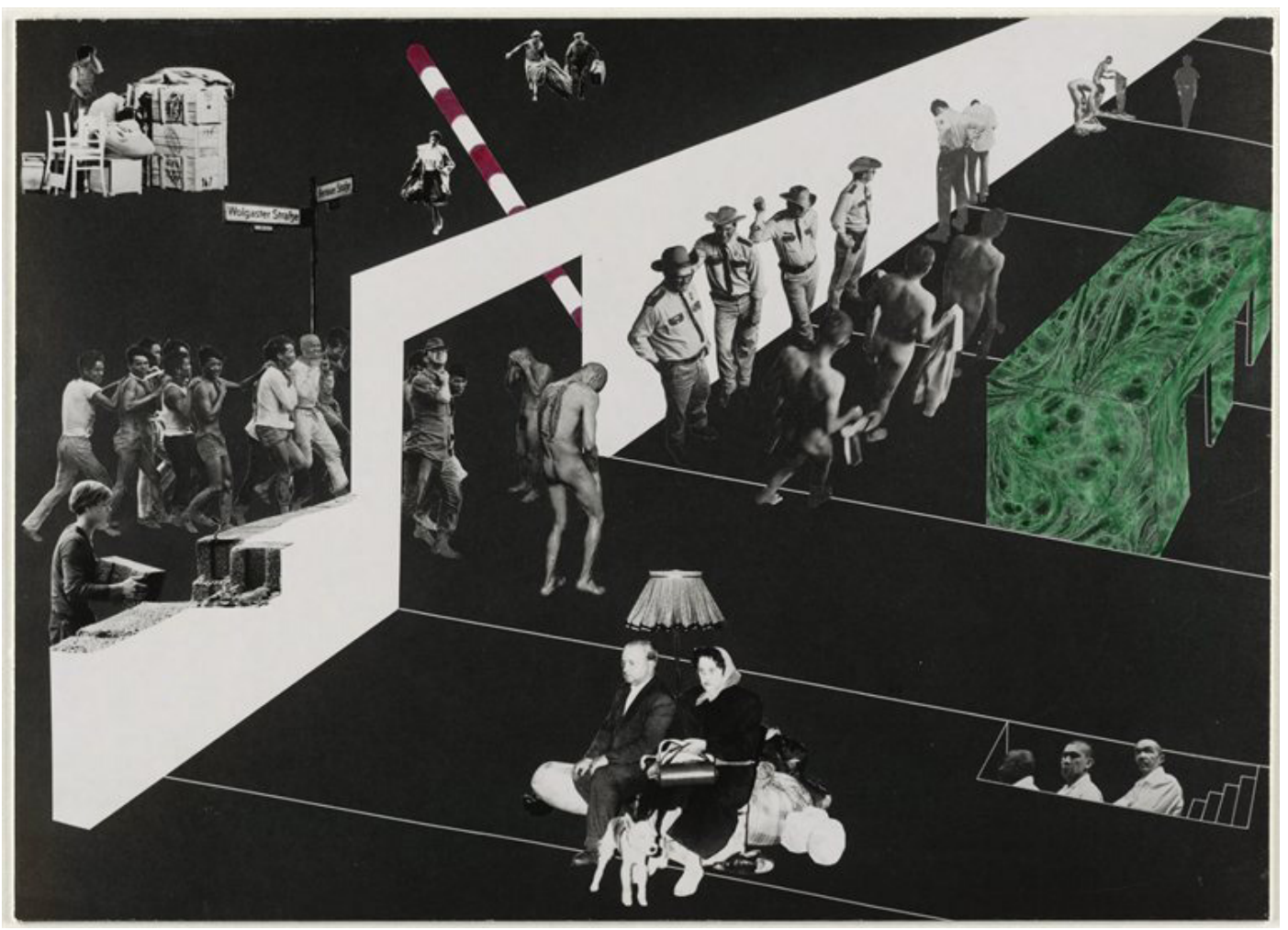

Figure 3: Rem Koolhaas and Elia Zenghelis with Madelon Vriesendorp and Zoe Zenghelis, Exodus, or the Voluntary Prisoners of Architecture The Reception Area, project 1972

\section{BORDERS STUDIO}

Given the political climate and the proximity of our school to the Border, I decided to incorporate some of these issues in the Studio that I taught last Spring semester.

The University of New Mexico is a Minority Serving Institution and therefore, a large population of our students is from the border region. As other schools in the country, after the plans to build the wall continued, our windows showed messages against it, but some students still didn't know how to articulate their thoughts or how they could create a bigger impact with their ideas.

Due to this situation, I decided to bring these conversations to the studio. This was an elective studio for fourth-year undergraduate students. The studio reached the maximum enrollment timely, and out of the eleven students that selected the studio, nine were originally from the US/Mexico border region.

\section{PROJECT\#1: KOREAN BATH HOUSE}

As a way to start the research in the US/Mexico border in a more objective manner, during the first part of the semester, we focused on a foreign border: the Korean Demilitarized Zone. The students participated in ArchOut Loud's competition to design a bathhouse in this border. (Fig. 4)

The students spent the first month of the semester studying different geopolitical boundaries as well as the history of the DMZ. Apart from it, they also studied how form implies political references and also how important graphic representation is when articulating such ideas.

After this preliminary analysis, the students came up with a concept for their design, which unavoidably, implied a political stand on the conflict. The students were also asked to carefully choose the representation technique or graphic style that they would use to communicate their ideas.

\section{PROJECT\#2: THIS IS NOT A WALL}

During the second part of the semester, the studio focused on the US/Mexico border. The students were asked to come up with projects for the US/Mexico Borderland. The brief didn't imply a stand on the conflict and the students were given freedom to express their ideas. The projects had to be developed in three different locations: on one of the two intersections of the area with the sea, on El Paso/Juarez and a third location that they could choose. (Fig. 5)

For this project, the students were asked to study the history of the border, study the multiple systems that co-exists in the area and understand the advantages and disadvantages that this infrastructure would bring to the place.

During the semester, we also visited El Paso and Juarez two times with the students and we also engaged with people from local communities on both sides of the border. After three weeks of research, the students were asked to come up with a design idea and draft a letter to the President describing the benefits of their proposal compared to the proposed wall. 
802091932

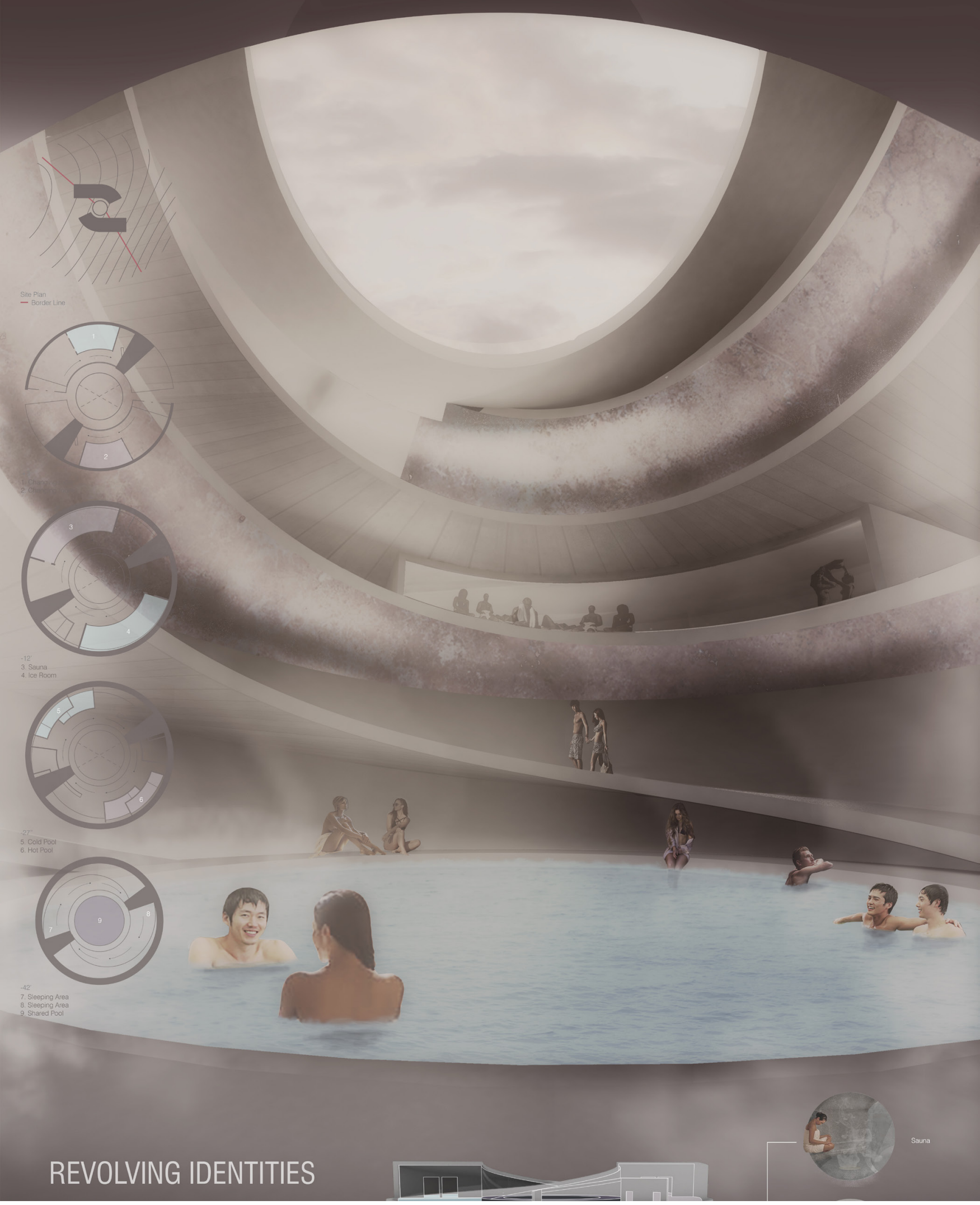




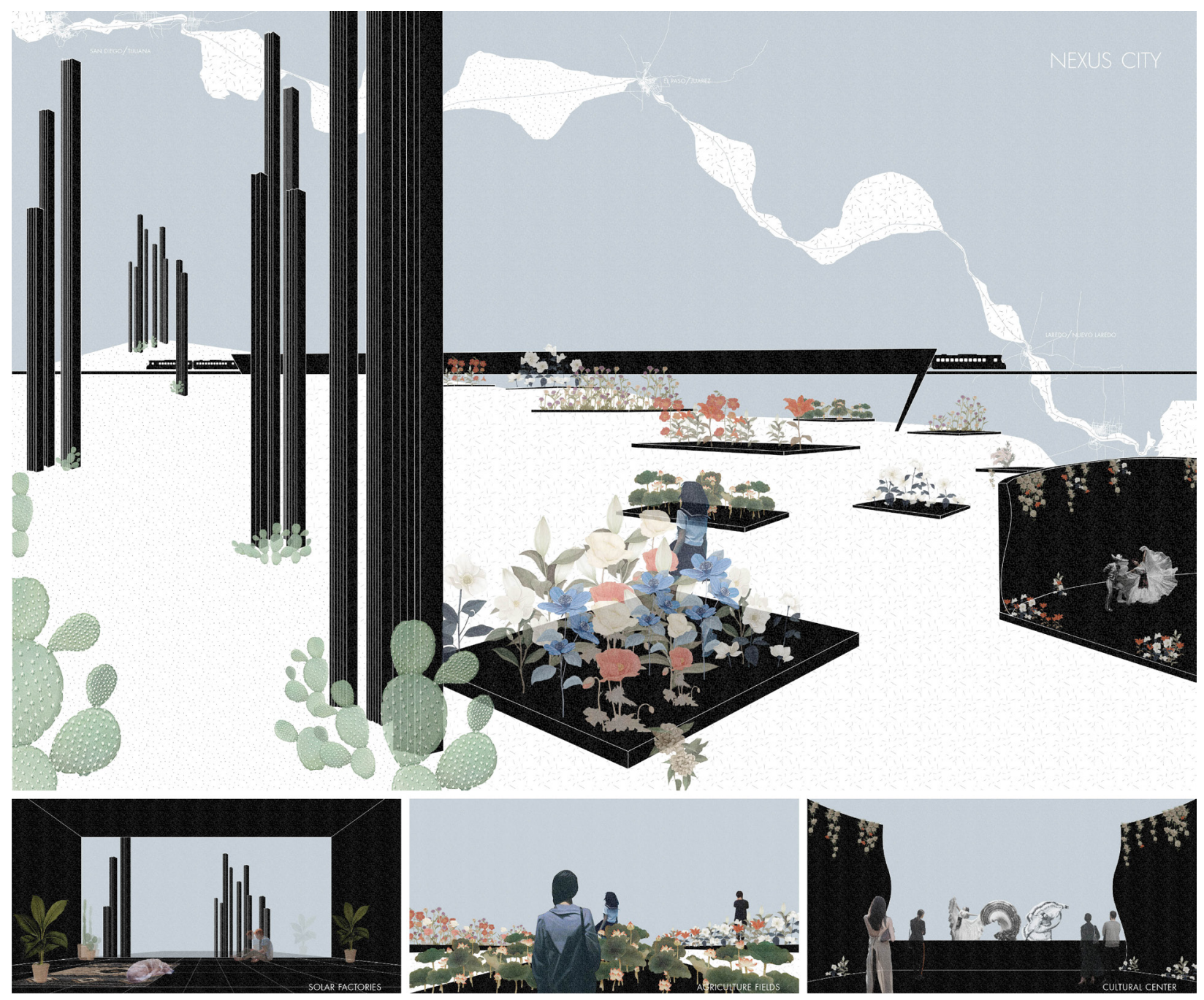

Figure 5: Nexus City, Mario Devora and Nicole Zollner

One of the students' proposals was titled "The gradient border" and defended the idea of the border not being a line in the ground, but a gradually changing landscape:

"The Gradient encompasses all of its extremities in a single composition creating transitions that combine traits of all extremities. The Western Hemisphere exists as a gradient canvas, diverse in all its components. However, acting as a single composition. The physical terrain transitioning itself over expanses of land creating distinct environments at their extremities, Northern Mountain Ranges to scorching deserts, to lushes tropical rainforests. For centuries humans, have inhabited the western hemisphere and had created diverse cultures thriving In the diverse landscape. (...) The Gradient world does not exist as single components that share a border, but a world that blends and transitions itself so elegantly that hard lines marking the extremities disrupt the composition of the western hemisphere. This is not Wall. But a reminder to ourselves that we exist today as people not of one side or the other, but a people that have deep roots connected with the history and land of the Western Hemisphere."
PROJECT \#3 - THIS IS NOT A WALL - CHAMIZAL PARK Finally, the students were asked to develop their ideas on a smaller scale. The area selected was the Chamizal Park, which is currently divided by the border in the El Paso/Juarez area. This allowed the students to narrow their project $s$ and understand how their idea for a 2,000mi area could also be scaled down to an urban scale.

Additionally, due to the attention that the studio was getting from other departments or even the local media, we decided to start a Twitter account in which to share our ideas and process.

During their research, the students understood that the problem with the wall in the architecture field wasn't the lack of design ideas, but the lack of consensus between architecture "as a practice" to stand against the wall altogether. The goal of the studio was to show the students that architecture can be (or should be) political and that their work should always be ethically in line with their principles. 


\section{CONCLUSION}

Considering that architecture differs from the other arts on its complexity and on its direct relation with economics and political forces, we can't deny the intrinsic implications and consequences that our work has in our society and planet. Neglecting these implications would be detrimental to our professional and ethical principles.

Regardless of what political side we are in, there is little doubt that the consequences of building a wall spanning 2000miles, would be catastrophic for both countries and their ecosystems. The impact that the wall would have in natural vegetation, ecosystems, and areas that are part of the National Parks system or Native American Reservations would be irreparable.

As architects, we should be aware of the systems that operate within our practice and define our role within these realities. Thinking that architecture is an isolated field in charge of beautifying structures will cause more problems and won't help us create more equitable environments.

As educators, bringing this issues to the studio setting and showing our students that there are a lot of options to be politically active within the profession without necessarily only having to be engaged in "paper architecture" might be a way to start introducing these conflicts to our students before they go into the profession.

In a time when walls are conceived as a dividing tool instead of as an opportunity to bring people and societies together, it can't be perceived as ethically sound to remain silent or give ambiguous answers to the problem.

\section{ENDNOTES}

1 Meeuwen, Mathilde van. "Walled Friends?! The Peculiar Coexistence of NAFTA and the US-Mexico Wall." Master's thesis, 2017

2 Federal Business Opportunities, online RFP, https://www.fbo.gov/index?s=opp ortunity\&mode $=$ form\& $i d=b 8$ 1b2a6876519ca0aedd748e1e491cf\&tab=core\&t abmode $=$ list $\&=$ (accessed September 4, 2017)

3 Miranda, Carolina A., "Trump's border wall may be controversial, but some Southern California firms want to build it". Los Angeles Times, (March 2, 2017). http://www.latimes.com/entertainment/arts/miranda/la-et-cam-border-wallpresolicitation-vendors-20170302-story.html (accessed September 4, 2017)

4 Ibid.

5 Pacheco, Antonio, "These architects want to critically engage with Trump's border wall”, Architects Newspaper, (March 3,3 2017). https://archpaper. com/2017/03/junejuly-border-wall/ (accessed September 4, 2017)

6 Hong, Sukjong, "The Problem with Designing Trump's Border Wall", New Republic, (March 29, 2016). https://newrepublic.com/article/132177/problemdesigning-trumps-border-wall (accessed September 4, 2017)

7 Korody, Nicholas, "US/Mexico border wall competition provokes controversy" Bustler, (March 16, 2017). http://bustler.net/news/tags/competition/326/4754/us-mexico-border-wall-competition-provokes-controversy/ competition-news (accessed September 4, 2017)

8 Building the Border Wall? Architecture competition website http://buildingtheborderwall.com/us-mexico-border-issues/ (accessed September 4, 2017)

9 Hong, Sukjong, "The Problem with Designing Trump's Border Wall", New Republic, (March 29, 2016). https://newrepublic.com/article/132177/problemdesigning-trumps-border-wall (accessed October 4, 2017)

10 Open letter to members and friends of the international AIA National Region. http://www.aiainternational.org/home/2016/12/1/open-letter-to-membersand-friends-of-the-aia-international.html (accessed September 4, 2017)

11 A post-election message from AIA's CEO and 2016 President https://vimeo. com/191580244 (accessed September 4, 2017)

12 Resolution on Alternatives to the Border Wall, Passed, September 19. 2017, AIA New Mexico.

13 The Architecture Exchange - How is Architecture Political? AA London, Mouffe in conversation with Aureli, Martin, Weizman and Whiting Series: The Architecture Exchange. (Saturday 6 December 2014)

14 Architecture and Capitalsm, Storefront for Art and Architecture, Peggy Deamer, Thomas Angotti, Quilian Riano and Michael Sorkin

15 Irina Vinnitskaya, MoMa Exhibit: 9+1 Ways of Being Political: 50 Years of Political Stances in Architecture and Urban Design

16 Juan Lázaro, "En Madrid y Barcelona han cerrado el 50\% de los estudios," Cinco Días.com, http://cinco dias.com/cincodias/2012/09/21/econo$\mathrm{mia} / 1348206985$ 850215.html (accessed October 4, 2016. 